\title{
Exploration of higher education in the context of cultural diversity
}

\author{
Bei JU \\ International Business Faculty \\ Beijing Normal University Zhuhai Campus \\ Zhuhai, People's Republic of China
}

\begin{abstract}
-paper tries to provide the solutions for the challenges of higher education in the context of cultural diversity. In the process of acculturation, international students will face up with diverse challenges. Therefore, it is worthwhile exploring about how to teach and learn effectively, especially when learners are of different learning style preferences. The solutions based upon culturally responsive teaching are under discussion to meet the needs of higher education in the 21 st century.
\end{abstract}

\section{Keywords- cultural diversity; higher education; challenges}

\section{INTRODUCTION}

The world is undergoing the trend of globalization. In this process, the higher education is facing challenges brought by educational internalization and multi-culture. The topic concerning about the international students, cultural diversity and higher education has drawn my attention since I started my career as a university teacher in 2006. I was a faculty member of $2+2$ international program in Faculty of International Business. Students registered in this program firstly study two years in mainland China and then further their study in our cooperated universities in the UK and Australia based on their IELTS and GPA. However, some of them failed and dropped out of the university overseas. Even successful students reported that they felt disappointed and struggled in the process of learning overseas. Enlightened by the feedback from students and our cooperated university, I realize that how to teach and learn effectively in the context of internationalization is a worthwhile question to explore in the current world of cultural diversity.

\section{CHALlENGES OF HIGHER EDUCATION}

In a mobile world, the acculturation is a recognized phenomenon. The widely accepted meaning of acculturation is defined by Redfield, Linton and Herskovits (1936) as "acculturation comprehends those phenomena which result when groups of individuals having different cultures come into continuous first-hand contact, with subsequent changes in the original culture patterns of either of both group". When international students start their learning and living in the new country, the changes of individuals will reflect the interactions of their home and host culture. Most of them will face up with the challenges of cultural diversity. In this new environment, shocks exist everywhere, such as language, value system and academia. When they are sitting together to learn, it seems an impossible task for teachers to accomplish.

Firstly, international students, as Asian students, may face up to the reality that they are the second language learners. Even they have scored a high mark in foreign language test, their language proficiency is insufficient to comprehend all the information delivered in the class, let alone the specialized knowledge. Secondly, teachers are challenged to carry out the effective teaching activities. It is difficult for teachers to satisfy all the students due to learners' individuality. This problem seems more severe when dealing with international students. The learning style preferences of international students may be completely distinct from those of their classmates. This fall semester, four students from France and Portugal participated in my Business Communication class. From my personal experience, I noted that four exchange students were more actively involved in my class than Chinese students, which could be reflected in terms of group discussion, case analysis and in-class quiz. They were willing to give feedbacks even if exchange students were not sure about the correctness of their answers. As Ramburuth and McCormick (2001) found that Asian international students demonstrated significantly higher use of deep motivation, surface strategies and achieving strategies, whist Australian students demonstrated higher use of deep strategies and surface motivation. Additionally, the learning style preferences of Asian and Australian students differ significantly in group, auditory, tactile and kinesthetic modes of learning. Additionally, what teaching materials will be most appropriate for both local and international students also pose a difficult question for instructors. More specifically, how to balance the current knowledge of students and what they have acquired and how to incorporate the culture differences into the teaching materials. In this sense, it is a tough job for teachers to choose teaching materials and motivate students, helping them participate in class.

Undoubtedly, the cultural diversity, as a variable, will result in complicated problems in university teaching. On the other hand, educational internationalization will be an unavoidable trend in the development of higher education. It is estimated that the number of Chinese international students has increased to 500,000 in 2014. Therefore, the answers to how can the higher education meet the needs of cultural diversity will provide the university teaching with novel ideas. 


\section{SOLUTIONS}

When facing the challenges of culture diversity, Gay (2000, p.29) proposed the idea of culturally responsive teaching, which places students' cultures at the core of the learning process and utilizes the "cultural knowledge, prior experiences, frames of references, and performance styles of ethnically diverse students", enabling teachers to mitigate cultures mismatches. This approach is based upon four foundational pillars of practice: teacher attitudes and expectations, cultural communication in the classroom, culturally diverse context in the curriculum and culturally congruent instructional strategies (Gay, 2000, p.44). The culturally responsive teaching uses the diverse instructional strategies in response to the different learning styles, integrates multicultural teaching materials into the syllabus and encourages students to express their ideas about each other's culture. In other words, students' culture is placed as the core of learning and teaching process.

The precondition to solve the challenges of cultural diversity in higher education is the recognition of cultural diversity. That depends on teachers' cultural awareness and attitudes. Yaozhong Lv (2014) suggested the importance and success of cultural diversity education implemented in the UK through reforms in educational planning, teachers training, curriculum design and pedagogy. If the teachers are able to recognize the differences resulted from multi-culture, this idea will assist them with course design, instruction and course assessment. Under the guidance of cultural awareness, solutions could be worked out to create a common culture in the learning environment that all learners can accept.

Firstly, teachers should make class accessible. If the lectures are delivered in complicated language far over the current level of students, students will feel frustrated and anxious, even give up their learning. As Otten (2003) stated that teachers should be responsible for creating an intercultural classroom climate. In order to overcome language barrier of second language learners, the complexity and wording may be chosen and decided according to the status quo of international learners. In this way, students won't lose their confidence or interests at the very beginning and then they will be motivated to actively participate in the class. Furthermore, the adoption of E-teaching will contribute to the accessibility of class. The tools such as mobile devices, tablet or social media all could be used to act as the bridge between instructors and students. Also, international online forums

Secondly, students should be encouraged to share their own values and ideas with each other. Small group discussion is an effective way to achieve this goal. By doing this, not only the questions could be examined from the multi-perspective, but the learning environment would be enhanced for the cognitive development of all learners. When the home culture of international students is respected, they will try to understand and accept the dominant culture. On the other hand, the local students are able to interact with international students and get to know the ideas of each other. To some extent, international students could be helped and supported by group members to achieve the common goal.
The activity, having discussion with local students, will serve as a positive role in the acculturation process of international students.

Thirdly, the design of curriculum and instructional strategies could be administrated in the context of diverse culture. Except from the cultural awareness of teachers, a culturally diverse teaching team will be a good choice to implement the effective teaching for students from diverse culture background. Teachers of the teaching team can collect materials reflecting the different culture and viewpoints and then incorporate them into the brand-new one due to the needs and levels of international learners. In the learning environment of multi-culture, it is important to involve teachers who themselves are from different cultural background to embrace the challenges of cultural diversity (Malin, 1999). In this way, it is easier for teachers to design and implement the course syllabus when indeed taking cultural differences into consideration.

\section{CONCLUSIONS}

It is a reality that students of cultural diversity attend universities and the increasingly number of international students has gained much attention of educator and scholars. Under this circumstance, being an effective university teacher means to be able to "respect" students except from imparting knowledge. Valuing cultural diversity in international education is a precondition of all-around development of higher education in the new era. The home culture co-exists with the dominate culture and the individuality of international students are maintain. In this process, teachers know who international students are, what do they need and how to help them. In terms of international students, learning is experiencing. They can learn from the past, and also can learn from the future. The key point is they are exploring the brand-new world of uncertainty. Overall, the teaching and learning in the $21^{\text {st }}$ century will definitely surpass the national and cultural boundaries. If you are feeling and searching for the new things as international students, you are learning no matter whether the outcomes are easy to predict or not. Leaning could be identified by the satisfaction of learners as well as their ability to solve the problems. Learners, international students, are the best approach to measure what has learnt by their own experience and exploration. From the perspective of university, as Cortese (2003) pointed out that a university would operate as a fully integrated community that models social and biological sustainability itself and in its interdependence with the local, regional and global communities. In this sense, the culturally responsive teaching will meet the needs of higher education in $21^{\text {st }}$ century.

\section{References}

[1] Cortese, A. (2003). The critical role of higher education in creating a sustainable future. Planning for higher education, March-May, 15-22.

[2] Gay, G. (2002). Culturally responsive teaching: theory, researcher, and practice. New York, NY: Teachers College Press.

[3] Malin, M. (1999). I'm rather tired of hearing about it: challenges in constructing an effective anti-racism teacher education program, Curriculum Perspectives, 19 (1), 1-11. 
[4] Otten, M. (2003). Intercultural Learning and Diversity in Higher Education. Journal of Studies in International Education, 7(1), 12-26.

[5] Ramburuth, P., \& McCormick, J. (2001). Learning diversity in higher education: a comparative study of Asian international and Australian students, Higher Education, 42, 333-350.

[6] Redfield,R., Linton, R. \& Herskovits, M.J. (1936). Memorandum for the study of Acculturation. American Anthropologist, 38(1). 149-152.
[7] Yaozhong Lv. (2014). Experiences and enlightenment from cultural diversity education in the UK. Contemporary Educational Science, 18, 48-51. 